\title{
Association between social support and adherence to anti-retroviral treatment in people living with HIV
}

\author{
Associação entre suporte social com adesão ao tratamento \\ antirretroviral em pessoas vivendo com o HIV \\ Asociación entre apoyo social con la adherencia al tratamento \\ antirretroviral en personas que viven con $\mathrm{VIH}$

\section{Rafael da Silva Oliveira ${ }^{a}$ Marcelo Ribeiro Primeira ${ }^{a}$ Wendel Mombaque dos Santos ${ }^{\mathrm{a}}$ Cristiane Cardoso de Paula ${ }^{a}$ Stela Maris de Mello Padoin ${ }^{a}$}

\section{How to cite this article:} Oliveira RS, Primeira MR, Santos WM Paula CC, Padoin SMM. Association between social support and adherence to anti-retroviral treatment in people living with HIV. Rev Gaúcha Enferm. 2020;41:e20190290. doi: https://doi. org/10.1590/1983-1447.2020.20190290 aniversidade Federal de Santa Maria (UFSM), Departamento de Enfermagem, Programa de PósGraduação em Enfermagem. Santa Maria, Rio Grande do Sul, Brasil.

\section{ABSTRACT}

Objective: To investigate the association between social support, adherence to HIV anti-retroviral therapy, and clinical and sociodemographic factors.

Method: A cross-sectional study conducted from July 2016 to August 2018 in a specialized outpatient clinic in southern Brazil. Individual interviews were conducted for the application of the following instruments: Questionnaire for the Evaluation of Adherence to Anti-retroviral Treatment (CEAT-HIV) and Social Support Scale for People Living with HIV/AIDS. The Spearman bivariate correlation test was used for analysis purposes.

Results: Among the 168 participants, the mean social support score was 3.53 points (SD $=0.66)$, and $64.9 \%(n=109)$ of the respondents had insufficient adherence. There was a significant association $(p<0.05)$ between emotional social support and the following adherence domains: antecedents of non-adherence behaviors and doctor-patient communication.

Conclusions: Social support is associated with antecedents of non-adherence behaviors and doctor-patient communication. Keywords: Social support. Acquired immunodeficiency syndrome. HIV. Anti-retroviral therapy, highly active. Medication adherence. Nursing.

RESUMO

Objetivo:Verificar associação entre suporte social, adesão ao tratamento antirretroviral para HIV e fatores clínicos e sociodemográficos. Método: Estudo transversal realizado em ambulatório especializado em município na região Sul do Brasil, entre julho de 2016 a agosto de 2018. Foram realizadas entrevistas individuais para aplicação dos instrumentos Cuestionario para la Evaluación de la Adhesión al Tratamiento Antiretroviral (CEAT-VIH) e a Escala de Suporte Social para pessoas vivendo com HIV/AIDS. Para análise utilizou-se o teste de correlação bivariada de Spearman.

Resultados: entre os 168 participantes, a média de suporte social foi de 3.53 (DP=0,66) e 64,9\% ( $n=109)$ apresentaram adesão insuficiente. Houve associação significativa $(p<0,05)$ entre o suporte social emocional com os domínios da adesão antecedentes de falha de adesão e comunicação médico-paciente.

Conclusões: 0 suporte social é associado com os antecedentes de falta de adesão e a comunicação médico-paciente.

Palavras-chave: Apoio social. Síndrome da imunodeficiência adquirida. HIV. Terapia antirretroviral de alta atividade. Adesão à medicação. Enfermagem.

\section{RESUMEN}

Objetivo: Determinar la asociación entre apoyo social, adherencia al tratamiento antirretroviral del VIH y factores clínicos y sociodemográficos.

Método: Estudio transversal realizado en una clínica ambulatoria especializada en un municipio del sur de Brasil, desde julio de 2016 hasta agosto de 2018. Se realizaron entrevistas individuales para aplicar los instrumentos Cuestionario para la Evaluación de la Adhesión al Tratamiento Antirretroviral (CEAT-VIH) y la Escala de Apoyo Social para personas que viven con VIH/SIDA. Para el análisis, se utilizó la prueba de correlación bivariada de Spearman.

Resultados: Entre los 168 participantes, el apoyo social promedio fue de 3.53 ( $D E=0.66)$, y el $64.9 \%(n=109)$ tuvo un nivel de adherencia insuficiente. Se registró una asociación significativa $(p<0.05)$ entre el apoyo social emocional y los siguientes dominios de adherencia: antecedente de incumplimiento y comunicación médico-paciente.

Conclusiones: El apoyo social se asocia con antecedentes de incumplimiento y comunicación médico-paciente.

Palabras clave: Apoyo social. Síndrome de inmunodeficiencia adquirida. VIH. Tratamiento antirretroviral altamente activo. Cumplimiento con respecto a la medicación. Enfermería. 


\section{口INTRODUCTION}

The changes in the profile of epidemic of the Human Immunodeficiency Virus (HIV) infection in Brazil are related to the successful Brazilian public policies, which included educational preventive measures, such as the use of condoms, and health care measures, such as provision of combined antiretroviral therapy (ART). These measures, along with the social response resulting from the organization of the civil society, strengthened the actions of the Brazilian State, thus ensuring universal and free access to the ART and allowing for a severe disease to be transformed into a chronic controllable disease ${ }^{(1)}$.

HIV infection can be controlled through the ART, which prevents viral replication and makes it possible to manage the infection. Therefore, treatment should start early and should not be interrupted ${ }^{(2)}$. Treatment adherence is a dynamic and multi-factorial process that encompasses physical, psychological, social, cultural, and behavioral aspects; moreover, it demands shared and co-responsible decision making among the people living with HIV (PLHIV), the health team, and the user's social network ${ }^{(2)}$.

This broadened concept of adherence enabled to produce scientific evidence on the importance of measuring users' perception about social support and its association with adherence promotion. Social support is a theoretical construct based on the relationship between availability of social support to a person and their satisfaction when facing a chronic disease ${ }^{(3)}$.

Previous studies show that PLHIV who live alone, are single, separated or widowed, or who did not reveal their diagnosis of HIV seropositivity received less everyday instrumental support with provision of food and clothes or assistance with everyday chores ${ }^{(4-5)}$. Additionally, it was found that this lack of instrumental support may be negatively associated with adherence to the ART ${ }^{(4-8)}$. Conversely, PLHIV receiving emotional support had an up to $7.9 \%$ greater likelihood of treatment adherence ${ }^{(4)}$.

In light of the evidence, analyzing the presence of factors intrinsic to emotional and/or instrumental support with more practical aspects of daily life and their association with adherence is essential for an effective and safe clinical management, based on the perception of those receiving such support, who, in the present study, consisted of PLHIV. Thus, the guiding question of this research was the following: Which social support factors are associated with adherence to HIV treatment? This study aimed to investigate the association between social support, adherence to HIV antiretroviral therapy, and clinical and sociodemographic factors.

\section{METHOD}

This is a cross-sectional study founded on a theoretical background about social support and treatment adherence ${ }^{(3,9)}$. The study participants consisted of PLHIV who underwent outpatient follow-up in a university hospital in the state of Rio Grande do Sul, Brazil.

The inclusion criteria were patients aged 18 years old or older, of both genders, who had been receiving anti-retroviral drugs for at least 3 months, because this period is considered sufficient for these drugs to achieve their therapeutic effect ${ }^{(2)}$. The exclusion criteria were the following: incarcerated people and pregnant women. The sample size calculation yielded a minimum population of 147 subjects. Data collection took place from July 2016 to August 2018, and the final sample size consisted of 168 subjects.

Three instruments were used for data collection. The population characterization variables were collected using an instrument built for this study and covering the following: age (complete years old); gender (female or male); race (white, black, yellow, brown, or indigenous); schooling (years of study); marital status (living with spouse or partner, single, separated, divorced, or widowed); monthly per capita income (Brazilian reais); employment status (active or inactive); length of diagnosis (months); route of infection transmission (sexual transmission, vertical transmission, needle sharing, occupational accident, or unknown); opportunistic infections (specify); psychiatric medication (specify). Data was collected through individual interviews conducted in a private room at the outpatient clinic, and the results of the viral load and CD4 tests were collected from the patients' medical records.

Social support was assessed using the Social Support Scale for People Living with HIV/AIDS, which was translated and adapted from the Social Support Inventory for People who are Positive or Have AIDS Canadian instrument ${ }^{(3)}$. It is a 5-point Likert scale that provides a mean score for its 26 items and covers two factors: 1) Emotional support, which relates to the perception and satisfaction concerning the availability of listening, attention, information, appreciation, company, and emotional support in relation to HIV seropositivity; 2) Instrumental support, which relates to the perception and satisfaction regarding the availability of support in the management or resolution of operational matters related to treatment or health care, practical activities of daily life, and material and/or financial aid. Higher scores indicate greater perceived availability and satisfaction with social support. The internal consistency of this scale was determined using Cronbach's alpha coefficient, with values greater than 0.7 indicating good consistency. 
Adherence to the ART was assessed using the validated and Portuguese-adapted version of the Questionnaire for the Assessment of Adherence to Anti-retroviral Therapy (Cuestionario para la Evaluación de la Adhesión al Tratamiento Antiretrovi$\mathrm{ral}, \mathrm{CEAT}-\mathrm{VIH})$. The questionnaire has 5 domains: compliance, antecedents of non-adherence behaviors, doctor-patient communication, personal beliefs and expectations about the treatment, and satisfaction with the treatment. It is worth noting that the dissemination of the instrument's questions is prohibited by the author of the scale. The questionnaire uses a 5-point Likert scale and contains 20 questions. Based on the score, the overall adherence can be classified into "inadequate" (up to 50 points), "insufficient" (from 51 to 85 points), and "strict/adequate" (from 86 to 100 points). To calculate the CEAT-VIH adherence scores, the answers of each study participant were entered on a website (www.ceat-vih.info), the CEAT-VIH psychometric properties being available only in its online version ${ }^{(9)}$.

The categorical variables were presented as absolute and relative frequencies, and the continuous variables as mean, standard deviation, median, minimum, and maximum, depending on the instrument. For the articulation between the instruments of sociodemographic and clinical characteristics, adherence, and social support, the Spearman's bivariate correlation (Rhô) test for non-parametric samples was performed in order to verify the relation among the variables. The level of confidence was set at 95\% ( $p$-value $<0.05$ ), with the ( $r$ ) coefficient ranging from -1 to 1 , where the two extremes represent perfect correlations, and $r=0$ represents no correlation.

This study is derived from the master's thesis entitled "Suporte social na adesão ao tratamento antirretroviral para o HIV" ("Social support in the adherence to the anti-retroviral therapy for HIV")(10), whose project was approved by the institution's Research Ethics Committee, under approved opinion No.1,538,216. The development of the study complied with the national ethical standards in research involving human beings, and the Free and Informed Consent Form was used prior to data collection.

\section{Q RESULTS}

A total of 168 PLHIV receiving ART participated in the study. In relation to the sociodemographic characterization variables of the patients, a mean schooling time of $8.2 \pm 3.30$ years of study and a mean monthly income of $R \$ 1,534.68 \pm 1,267.70$ are highlighted, the patients being employed or not at the time of the interview. The clinical characteristics refer to route of transmission, time of diagnosis of $168 \pm 85.66$ (months) and duration of the treatment of $168 \pm 78.70$ (months), as well as the use of drugs and other medications.

It is verified that some of the patients reported not knowing their route of infection transmission, that the maximum time of diagnosis and duration of treatment was 39 years, and that many participants reported not making any change in their lifestyles after being diagnosed with HIV infection (Table 1).

Instrumental social support had a higher mean score (3.73 points); however, emotional social support presented a higher Cronbach's alpha coefficient (Table 2).

The main sources of social support were the following: spouse/partner/boyfriend or girlfriend for $44.6 \%(n=75)$ of the respondents, and the relatives living in the same household for $41.1 \%(n=69)$. When the social support factors were stratified into emotional support and instrumental support, the following sources of emotional support were found: relatives not living in the same household for $43.5 \%(n=73)$ of the respondents; friends, for $8.9 \%(n=15)$; neighbors, for $2.4 \%(n=4)$; and health care professionals, for $3 \%(n=5)$. Conversely, the sources of instrumental support were the following: relatives not living in the same household for $48.2 \%(n=81)$ of the respondents; friends, for $41.1 \%(n=69)$; neighbors, for $8.9 \%(n=15)$; and health care professionals, for $6 \%(n=10)$.

With regard to the results for adherence to the ART, $64.9 \%(n=107)$ of the respondents were classified as having insufficient adherence; 33.9\% ( $n=55)$ as having strict/ adequate adherence, and $1.2 \%(n=2)$ as having inadequate adherence. The scores of the adherence domains are quantified in Table 3.

The correlations between the sociodemographic variables and the social support factors are presented in Table 4, with instrumental support being weakly correlated with the number of people relying on the income and the duration of the treatment. As for the emotional support, a significant correlation was observed with monthly income, number of people relying on the income, and time of diagnosis. As regards total social support, monthly income, number of people relying on the income, time of diagnosis, and duration of the treatment were significant.

A weak but positive correlation was evidenced between emotional support and the following adherence domains: antecedents of non-adherence behaviors, doctor-patient communication, and overall adherence; moreover, total social support was positively correlated with doctor-patient communication. These results are shown in Table 5. 
Oliveira RS, Primeira MR, Santos WM, Paula CC, Padoin SMM

Table 1 - Sociodemographic and clinical characteristics of the sample of adults receiving ART for HIV, RS, Brazil, 2019

\begin{tabular}{lc} 
Characteristics & $\mathbf{n = 1 6 8 ( \% )}$ \\
Female gender & $95(56.5)$ \\
White race & $108(64.3)$ \\
Lives with spouse or partner & $85(50.6)$ \\
Unemployed & $103(61.3)$ \\
Not using drugs & $147(87.5)$ \\
Not using alcoholic beverages & $132(78.6)$ \\
No change in lifestyle & $97(57.7)$ \\
HIV sexual transmission route & $119(70.8)$ \\
No opportunistic disease & $102(60.7)$ \\
Not using psychiatric medications & $130(77.4)$ \\
Undetectable viral load & $130(77.4)$ \\
\hline
\end{tabular}

Source: Research data, 2019.

Table 2 - Scores of the social support factors in the sample of adults receiving ART for HIV, RS, Brazil, 2019

\begin{tabular}{|c|c|c|c|c|c|}
\hline \multirow{2}{*}{ Social Support factors } & \multicolumn{4}{|c|}{ Score } & \multirow{2}{*}{ Cronbach's alpha } \\
\hline & Mean & Min & Max & SD & \\
\hline Emotional & 3.35 & 1.90 & 5.00 & 0.71 & 0,851 \\
\hline Instrumental & 3.73 & 1.80 & 5.00 & 0.77 & 0,745 \\
\hline Total & 3.53 & 1.80 & 5.00 & 0.66 & 0,878 \\
\hline
\end{tabular}

Source: Research data, 2019

Caption: Minimum: Min; Maximum: Max; Standard Deviation: SD.

Table 3 - Scores of the domains of treatment adherence in the sample of adults receiving ART for HIV, RS, Brazil, 2019

\begin{tabular}{lcccc} 
Domain & Mean & Min & Max & SD \\
\hline Compliance with the prescription & 84.20 & 33.00 & 100.00 & 15.27 \\
Antecedents of non-adherence behaviors & 90.74 & 31.00 & 100.00 & 11.81 \\
Doctor-patient communication & 80.39 & 8.00 & 100.00 & 15.55 \\
Beliefs and expectations about treatment & 76.55 & 30.00 & 100.00 & 14.21 \\
Satisfaction with the treatment & 76.35 & 25.00 & 100.00 & 18.01 \\
Overall adherence & 81.71 & 47.00 & 97.00 & 8.70 \\
\hline
\end{tabular}

Source: Research data, 2019.

Caption: Minimum: Min; Maximum: Max; Standard Deviation: SD 
Table 4 - Spearman's correlation (Rhô) between sociodemographic variables and social support of the sample of adults receiving ART for HIV, RS, 2019

\begin{tabular}{lcccccc} 
& \multicolumn{2}{c}{ Instrumental } & \multicolumn{2}{c}{ Emotional } & \multicolumn{2}{c}{ Total } \\
\cline { 2 - 7 } Variable & Coefficient & $\mathbf{p}$ & Coefficient & $\mathbf{p}$ & Coefficient & $\mathbf{p}$ \\
Monthly income & 0.121 & 0.118 & $\mathbf{0 . 1 7 9}$ & $\mathbf{0 . 0 2 0}$ & $\mathbf{0 . 1 6 5 ^ { * }}$ & $\mathbf{0 . 0 3 3}$ \\
People relying on the income & $\mathbf{0 . 1 5 6 ^ { * }}$ & $\mathbf{0 . 0 4 4}$ & $\mathbf{0 . 1 8 6 ^ { * }}$ & $\mathbf{0 . 0 1 6}$ & $\mathbf{0 . 1 8 0 ^ { * }}$ & $\mathbf{0 . 0 1 9}$ \\
Time of diagnosis & $\mathbf{0 . 1 9 4}^{*}$ & $\mathbf{0 . 0 1 2}$ & $\mathbf{- 0 . 2 0 2 ^ { * }}$ & $\mathbf{0 . 0 0 9}$ & $\mathbf{- 0 . 2 1 4 ^ { * }}$ & $\mathbf{0 . 0 0 5}$ \\
Duration of treatment & $\mathbf{0 . 1 6 2}^{*}$ & $\mathbf{0 . 0 3 6}$ & -0.134 & 0.083 & $\mathbf{- 0 . 1 6 7}^{*}$ & $\mathbf{0 . 0 3 0}$ \\
\hline
\end{tabular}

Source: Research data, 2019

*Significant correlation for $p \leq 0.05$

Table 5 - Spearman's correlation (Rhô) between social support and its factors, and adherence and its domains of the sample of adults receiving ART for HIV, RS, 2019

\begin{tabular}{lcccccc}
\multirow{2}{*}{$\begin{array}{l}\text { Social Support } \\
\text { factors }\end{array}$} & \multicolumn{2}{c}{ Antec. } & \multicolumn{2}{c}{ Commun. } & \multicolumn{2}{c}{ Overall adherence } \\
\cline { 2 - 7 } & Coefficient & $\mathbf{p}$ & Coefficient & $\mathbf{p}$ & Coefficient & $\mathbf{p}$ \\
\hline Instrumental & -0.002 & 0.981 & 0.149 & 0.057 & 0.027 & 0.735 \\
Emotional & $\mathbf{0 . 2 3 4 ^ { * }}$ & $\mathbf{0 . 0 0 3}$ & $\mathbf{0 . 2 3 4 ^ { * }}$ & $\mathbf{0 . 0 0 3}$ & $\mathbf{0 . 1 9 6}$ & $\mathbf{0 . 0 1 2}$ \\
Total & 0.115 & 0.141 & $\mathbf{0 . 2 0 2 ^ { * }}$ & $\mathbf{0 . 0 0 9}$ & 0.117 & 0.134 \\
\hline
\end{tabular}

Source: Research data, 2019.

*The correlation (rs) is significant (sig) at the 0.05 level (2 extremities)

Caption: Antec:. Antecedents of non-adherence behaviors; Commun.: Doctor-patient communication.

\section{DISCUSSION}

The participants in this study have sociodemographic characteristics similar to those of PLHIV from different regions in Brazil. This indicates that it may be possible to generalize the results, also considering that the predominance of males observed in the present study has also been reported in other studies ${ }^{(11-12)}$ and in the Brazilian national epidemiological bulletin ${ }^{(2)}$.

The mean number of years of schooling reveals that most of the participants completed primary school education, which reinforces the need of health care educational actions that adopt a language designed to facilitate understanding on patient's clinical status and on the ART. Having good schooling helps in understanding the infection process and thus contributes to acceptance and compliance with the treatment prescribed to maintain good health ${ }^{(13)}$.

As for the clinical characteristics of the participants, the mean duration of the treatment was 101.23 months ( $S D=78.7)$, whereas the mean time of diagnosis was 126.85 months $(\mathrm{SD}=85.7)$. The time interval between diagnosis and the beginning of the treatment did not lead to opportunistic diseases, a finding in line with that of a recent study conducted in the city of Rio de Janeiro, Brazil(14).

The social support scores were considered satisfactory, with the instrumental factor (3.73) showing slightly higher scores than those for the emotional factor (3.35). This indicates that the participants in the present study were more satisfied with the support received in their daily lives that help in maintaining treatment, considered as the management or resolutions of operational issues, including material or financial aid. Such support occurred independently from emotional support, which relates to satisfaction with the availability of company, listening, attention, and information. Other studies found similar results and considered the scores as satisfactory ${ }^{(7,11,15)}$.

Consistently with other studies $(6,7,11,15)$, the nuclear family, i.e., parents, children, siblings, and spouses, was the source of support most cited by PLHIV. It was observed that these people belong to the closest primary support network of the participants, with whom they have a relationship of trust, presumably established a long time ago.

Some variables were evidently related, such as social support, and monthly income was the only to be correlated solely with the emotional factor. Although access to 
treatment is free in Brazil, low income may be a barrier to satisfaction with perceived social support ${ }^{(11)}$. In the present study, the mean salary income was approximately $R \$ 1,534.00$, corresponding to nearly 1.5 minimum wages at the time of the study. However, most of the respondents reported not having an employment relationship at the time of the interview, which may have an impact on the living conditions of these people. Additionally, economic deprivation may have a negative impact on access to the health care services, for example, when PLHIV are required to travel to larger cities for access to specialized services ${ }^{(7,11)}$.

Financial concerns may be related to means of transportation and also to following an appropriate diet to maintain good health. This may interfere with the patient's treatment, thus leading to stressful situations and having an impact on treatment adherence and dissatisfaction ${ }^{(16)}$. Therefore, it is possible to infer that the extent of concern with income is related to the number of people relying on this income.

In the present study, the number of people relying on the income was correlated with instrumental and emotional factors of social support, a finding in line with other studies ${ }^{(7,11)}$. Hence, the higher the number of people relying on the income, the greater the concern about their financial situation. Conversely, these people have more support in situations when income may be a factor that may lead to low support and hamper treatment adherence. Furthermore, individuals living alone may receive less instrumental support compared to those living with other people, which may have a negative impact on health care, practical daily activities and financial help ${ }^{(4,17)}$.

The time of diagnosis was important for both factors of social support. In a study conducted in northeastern Brazil, a time of diagnosis below three years had a positive influence on the instrumental support scores ${ }^{(11)}$. This evidence may indicate that, after a recent the diagnosis, PLHIV receive more instrumental support because the people in their support network become aware of their disease status ${ }^{(11,15)}$. Therefore, it can be said that, at the beginning of the treatment, PLHIV receive more information and more assistance from their support network to maintain their health care, which shows that the therapeutic plan developed by the health team should include strategies to assess the availability of this availability in the families.

As for the issues related to treatment adherence evaluated in this study, the mean overall adherence showed an improvement compared with a previous study that assessed adherence in the same setting ${ }^{(18)}$. However, most of the participants in the present study presented scores showing insufficient adherence during the data collection period. In other Brazilian studies with similar populations, the mean scores ranged from insufficient adherence ${ }^{(18)}$ to adequate/ strict adherence ${ }^{(12)}$. Achieving adequate adherence is essential to ensure viral suppression over the years, thus reducing the likelihood of illness, of mutations to more resistant viral strains, and of HIV transmission ${ }^{(11,14,19)}$.

Statistical tests were performed to correlate social support with treatment adherence, and the result was that emotional support was significantly associated with antecedents for the non-adherence behaviors and for doctor-patient communication. It is possible that the influence of emotional social support from the family and from other significant people promotes adherence behavior, improving compliance with guidance from health care professionals and increasing the scores for the doctor-patient communication domain.

Having emotional support leads PLHIV to feel psychologically well and motivated to comply with treatment. These findings show that, for a successful treatment, a certain degree of joint responsibility between the health care professionals and the patient must be established. This should be mediated by an honest communication about all the aspects of treatment, the side effects, the use of alcohol and other substances, damage reduction, and clarifications on the infection ${ }^{(20)}$. Thus, PLHIV may feel in control of their treatment and motivated to maintain a routine for the use of medications, consultations, and other health care activities.

\section{CONCLUSIONS}

This study reported a mean score of 3.53 points for total social support, which represents approximately $70 \%$ of the maximum score. It was verified that social support has a positive impact on adherence to ART and that is associated with antecedents of non-adherence behaviors and doctor-patient communication. Moreover, the main source of support were the patients' families.

The findings of the present study show the need of health care strategies that allow for the early monitoring of possible adherence failures, either temporary or in the long term. It is also worth highlighting the need of an efficient communication between patients and health care team and of the assessment of the support network for PLHIV, thus improving the conditions for the promotion of adherence.

There are several instruments to assess adherence and social support; however, the association of the instruments used in this study is limited in the literature, which made it difficult to establish relationships between this study and published investigations with similar designs and contexts. Therefore, further studies are needed to reinforce the aim of this study, in order to strengthen evidence-based practice in health care and nursing actions. 


\section{REFERENCES}

1. Barros SG, Silva LMV. A terapia antirretroviral combinada, a política de controle da Aids e as transformações do Espaço Aids no Brasil dos anos 1990. Saúde Debate. 2017;41(spe3):114-28. doi: https://doi.org/10.1590/0103-11042017s309

2. Ministry of Health (BR). Secretaria de Vigilância em Saúde. Departamento de Vigilância, Prevenção e Controle das Infecções Sexualmente Transmissíveis, do HIV/ Aids e das Hepatites Virais. Protocolo Clínico e Diretrizes Terapêuticas para Manejo da Infecção pelo HIV em Adultos. Brasília, DF: Ministério da Saúde; 2018.

3. Seidl EMF, Tróccoli BT. Desenvolvimento de escala para avaliação do suporte social em HIV/aids. Psic Teor Pesqui. 2006;22(3):317-26. doi: https://doi. org/10.1590/S0102-37722006000300008

4. Lenzi L, Tonin FS, Souza VR, Pontarolo R. Suporte social e HIV: relações entre características clínicas, sociodemográficas e adesão ao tratamento. Psic Teor Pesq. 2018;34:e34422. doi: https://doi.org/10.1590/0102.3772e34422

5. Santos VF, Pedrosa SC, Aquino PS, Lima ICV, Cunha GH, Galvão MTG. Social support of people with HIV/AIDS: the Social Determinants of Health Model. Rev Bras Enferm. 2018;71(Suppl 1):625-30. doi: https://doi. org/10.1590/0034-7167-2017-0346

6. Kelly JD, Hartman C, Graham J, Kallen MA, Giordano TP. Social support as a predictor of early diagnosis, linkage, retention, and adherence to HIV care: results from the steps study. J Assoc Nurses AIDS Care. 2014;25(5):405-13. doi: https://doi.org/10.1016/j.jana.2013.12.002

7. SeidlEMF,ZannonCML,TrócoliBT.Pessoas vivendo comHIV/AIDS:enfrentamento, suporte social e qualidade de vida. Psicol Reflex Crit. 2005;18(2):188-95. doi: https://doi.org/10.1590/S0102-79722005000200006

8. Camargo LA, Capitão CG, Filipe EMV. Saúde mental, suporte familiar e adesão ao tratamento: associações no contexto HIV/Aids. Psico-USF. 2014;19(2):221-32. doi: https://doi.org/10.1590/1413-82712014019002013

9. Silva BB, Brito A, Monteiro EP, Mondelo GP, Remor E. Evidence of validity for the online version of the Assessment of Adherence to Antiretroviral Therapy Questionnaire. SAGE Open. 2019;9(3):1-12. doi: https://doi. org/10.1177/2158244019877201

10. Oliveira RS. Suporte social na adesão ao tratamento antirretroviral para o HIV [dissertação]. Santa Maria (RS): Centro de Ciências da Saúde, Universidade Federal de Santa Maria; 2019

11. Pedrosa SC, Fiuza MLT, Cunha GH, Reis RK, Gir E, Galvão MTG, Carvalho AF. Social support for people living with acquired immunodeficiency syndrome. Texto Contexto Enferm. 2016;25(4):e2030015. doi: https://doi. org/10.1590/0104-07072016002030015

12. Souza G0, Tibúrcio AACM, Koike MK. Appropriate adherence to antiretroviral therapy in the Alto Paranaiba, Minas Gerais, Brazil. Med Express. 2016;3(3):M160305. doi: https://doi.org/10.5935/MedicalExpress.2016.03.05
13. Silva JAG, Dourado I, Brito AM, Silva CAL. Factors associated with non-adherence to antiretroviral therapy in adults with AIDS in the first six months of treatment in Salvador, Bahia State, Brazil. Cad Saúde Pública. 2015;31(6):1188-98. doi: https://doi.org/10.1590/0102-311X00106914

14. Lima TA, Beyrer C, Golub JE, Mota JC, Malta MS, Silva CMFP, et al. Inequalities in HAART uptake and differential survival according to exposure category in Rio de Janeiro, Brazil. Cad Saúde Pública. 2018;34(8):e00009617. doi: https://doi. org/10.1590/0102-311x00009617

15. SantosWM, Padoin SMM, Magnago TSBS, Dalmolin GL, Zuge SS. Factors involved between social support and self-efficacy in HIV-infected individuals. Sci Med. 2015;25(2):ID21105. doi: https://doi.org/10.15448/1980-6108.2015.2.21105

16. Bittencourt GKGD, Moreira MASP, Meira LCS, Nóbrega MML, Nogueira JA, Silva A0. Beliefs of older adults about their vulnerability to HIV/Aids, for the construction of nursing diagnoses. Rev Bras Enferm. 2015;68(4):579-85. doi: https://doi.org/10.1590/0034-7167.2015680402i

17. Forouzan AS, ShushtariZJ, Sajjadi H, SalimiY, Dejman M. Social support network among people living with HIV/AIDS in Iran. AIDS Res Treat. 2013;2013:ID715381. doi: https://doi.org/10.1155/2013/715381

18. Primeira MR, Santos EEP, Züge SS, Magnago TSBS, Paula CC, Padoin SMM. Avaliação da adesão ao tratamento antirretroviral de pessoas vivendo com HIV. Saúde Pesqui.2018;11(2):307-14. doi:http://dx.doi.org/10.17765/2176-9206. $2018 v 11 n 2 p 307-314$

19. Foresto JS, Melo ES, Costa CRB, Antonini M, Gir E, Reis RK. Adherence to antiretroviral therapy by people living with HIV/AIDS in a municipality of São Paulo. Rev Gaúcha Enferm. 2017;38(1):e63158. doi: https://doi. org/10.1590/1983-1447.2017.01.63158

20. BellenzaniR,NemesMIB, PaivaV. Health professional-patientcommunicationand care: evaluation of an intervention for HIV/AIDS treatment adherence. Interface Comun Saúde Educ. 2013;17(47):803-34. doi: https://doi.org/10.1590/180757622013.0051

\section{Acknowledgments:}

To the University Hospital of Santa Maria, on behalf of the Federal University of Santa Maria, and its respective users of the Unified Health System. To the Institutional Programs of Scientific Initiation Scholarships (PIBIC/CNPq, PROIC/ HUSM, PROBIC/FAPERGS). To the National Council of Science and Technology (CNPq; Research Productivity Scholarship - Level 1D; granted to Stela Maris de Mello Padoin); Call: Universal 2016. Process: 408709/20162. Project title: Adherence to HIV Anti-retroviral Therapy: intervention and control. To the Coordination for the Improvement of Higher Level Personnel (Coordenação de Aperfeiçoamento de Pessoal de Nivel Superior, CAPES; Social Demand Scholarship granted to Marcelo Ribeiro Primeira).

\section{- Corresponding author:}

Stela Maris de Mello Padoin

E-mail: stelamaris_padoin@hotmail.com

\section{Associate editor: \\ Rosana Maffacciolli}

